\title{
Pseudohypopyon immediately after intravitreal injection of triamcinolone acetonide - Case reports
}

\author{
Pseudohipópio pós-injeção intravítrea de triancinolona-Relatodecasos
}

\author{
Vânia Ewert de Campos ${ }^{1}$ \\ André Maia ${ }^{2}$ \\ Cristina Muccioli ${ }^{3}$ \\ Rubens Belfort Jr. ${ }^{4}$
}

\begin{tabular}{l} 
ABSTRACT \\
\hline Report on the development of pseudohypopyon immediately after intravi- \\
treal injection of triamcinolone acetonide (TAAC). Two phakic patients \\
presenting with a transient pseudohypopyon after having been treated with \\
intravitreal triamcinolone. One had a clinically significant macular edema \\
with cystoid component (CSME with CMS) and the other, active Vogt- \\
Koyanagi-Harada(VKH) with serous retinal detachment of the macula. One \\
eye from each patient developed a pseudohypopyon with crystal deposits \\
adherent to the corneal endothelium. In one case it appeared right after the \\
injection and disappeared spontaneously in 24 hours. In the other patient \\
it appeared on day 3 and disappeared also spontaneously within 2 days. \\
The pseudohypopyon is an important sign that can be observed after \\
intravitreal injection of TAAC, in phakic patients, with spontaneous \\
resolution and without complication. The pseudohypopyon caused by the \\
deposition of TAACin the anterior chamber immediately after its injection \\
into the vitreous should be differentiated from other forms of hypopyon \\
associated with this type of treatment.
\end{tabular}

Keywords: Uveitis; Eye diseses/chemically induced; Eye diseases/physiopathology; Triamcinolone/adverse effects; Triamcinolone/therapeutic use; Adrenal cortex hormones/ adverse effects; Injections; Differential diagnosis; Case report [Publication type]

\section{INTRODUCTION}

Triamcinolone acetonide (TAAC) is a potent, relatively insoluble steroid that has been used for various ocular diseases, and shown to be of benefit for the control of intraocular inflammation, especially in patients with vitreoretinopathy and resistant long-standing uveitis ${ }^{(1-2)}$. The most common side effects observed after intravitreal TAAC are elevated intraocular pressure (IOP) and progressive lens opacity ${ }^{(1-6)}$. Hypopyon also has been described. We present here two phakic patients, who developed pseudohypopyon immediately after TAAC intravitreal injection and which resolved without specific treatment.

\section{Case 1}

34-year-old woman, with Vogt-Koyanagi-Harada (VKH), with acute bilateral serous detachment; visual acuity of count fingers at 2 meters in both eyes (OU), no anterior chamber reaction and intraocular pressure (IOP) of $12 \mathrm{mmHg}$ OU, was treated with an intravitreal injection of TAAC $(0.1 \mathrm{ml})$ in the right eye. Immediately after the injection we could observe a semifluid substance accumulating in the inferior part of the anterior chamber forming a pseudohypopyon, and crystal deposits that accumulated on the endothe- 


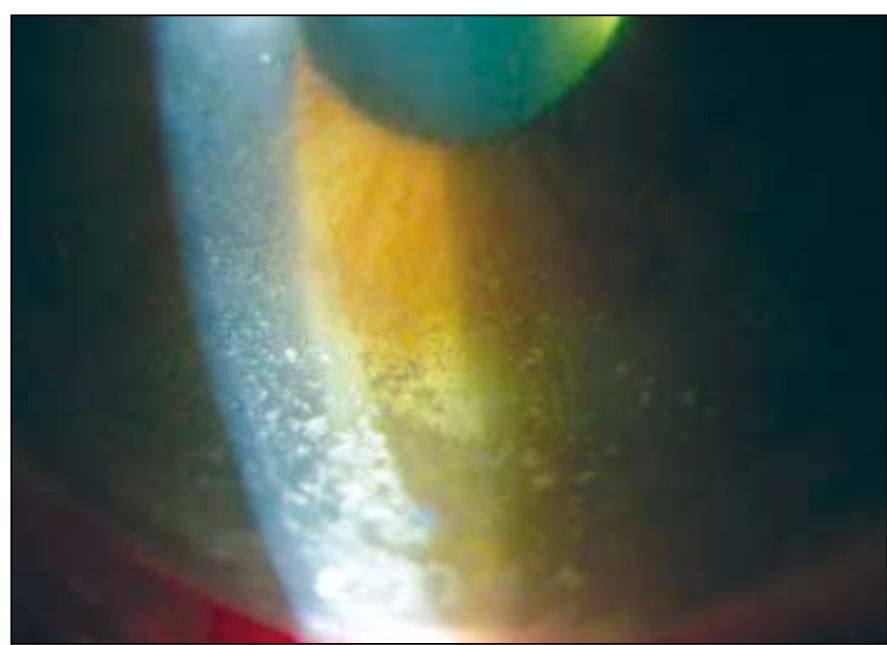

Figura 1 - Pseudohypopyon, with crystal deposits adherent to the endothelial surface of the cornea

lial surface of the cornea. There was no pain or rise in the intraocular pressure. One day later the pseudohypopyon had disappeared and the crystal deposits were observed in the corneal endothelium, for more 2 days.

\section{Case 2}

A 58-year-old diabetic man, with a best corrected visual acuity of 20/40 in OD and 20/400 in OS, no anterior chamber reaction and an IOP of $18 \mathrm{mmHg}$ OU. The fundoscopic examination disclosed a proliferative diabetic retinopathy with clinically significant macular edema OU and with cystoid component in OS. He was treated with an intravitreal injection of TAAC $(0.1 \mathrm{ml})$ and developed, 3 days after the injection a pseudohypopyon, with crystal deposits adherent to the endothelial surface of the cornea (Figure 1). In 3 days, the pseudohypopyon resolved spontaneously.

\section{DISCUSSION}

In theses cases, TAAC was present in the anterior chamber and sediment like a hypopyon right after the intravitreal injection in one patient resolving in one day. In the other patient it appeared 3 days after the injection and persisted for 2 days. In both patients it resolved completely without treat- ment. The pseudohypopyon may occur after intravitreal injection of triamcinolone, and seems to be a distinct clinical entity that may resolve without specific treatment.

\section{RESUMO}

Descrição de dois casos de pacientes submetidos à injeção intravítrea de acetonida de triancinolona (AT), que desenvolveram pseudo-hipópio transitório. Um paciente apresentava edema macular diabético clinicamente significativo com componente cistóide e o outro, com descolamento seroso de retina agudo com Vogt-Koyanagi-Harada, e ambos desenvolveram pseudo-hipópio com presença de depósitos de cristais no endotélio corneano; em um caso o pseudo-hipópio desapareceu espontaneamente em 24 horas, no outro caso o pseudohipópio teve duração de 2 dias. O pseudo-hipópio é importante sinal que pode ser observado após injeção intravítrea de AT, em pacientes fácicos, apresentando resolução espontânea sem complicações. Este pseudo-hipópio causado por depósitos de cristais de AT deve ser considerado diagnóstico diferencial para hipópio infeccioso associado a este tipo de tratamento.

Descritores: Uveíte; Oftalmopatias/induzido quimicamente; Oftalmopatias/fisiopatologia; Triancinolona/efeitos adversos; Triancinolona/uso terapêutico; Corticosteróides/efeitos adversos; Injeções; Diagnóstico diferencial; Relatos de casos [Tipo de publicação]

\section{REFERENCES}

1. Jonas JB, Hayler JK, Panda-Jonas S. Intravitreal injection of crystalline cortisone as adjuntive treatment of proliferative vitreoretinopathy. $\mathrm{Br} \mathrm{J}$ Ophthalmol. 2000;84(9):1064-7

2. Benitez Del Castillo Sánches JM, Garcia Sánches J. Inyección intravítrea de triamcinolona acetónido en uveitis no infecciosas. Arch Soc Esp Oftalmol. 2001;76(11):661-4.

3. Danis RP, Ciulla TA, Pratt LM, Anliker W. Intravitreal triamcinolone acetonide in exudative age-related macular degeneration. Retina. 2000;20(3):244-50.

4. Chandler DB, Rozakis G, de Juan E Jr, Machemer R. The effect of triamcinolone acetonide on a refined experimental model of proliferative vitreoretinopathy. Am J Ophthalmol. 1985;99(6):686-90.

5. Tano Y Chandler D, Machemer R. Treatment of intraocular proliferation with intravitreal injection of triamcinolone acetonide. Am J Ophthalmol. 1980;90 (6):810-6.

6. Antcliff RJ, Spalton DJ, Stanford MR, Graham EM, Ffytche TJ, Marshall J. Intravitreal triamcinolone for uveitic cystoid macular edema: an optical coherence tomography study. Ophthalmology. 2001;108(4):765-72.

\section{Ao enviar um artigo para publicação, leia ATENTAMENTE as instruções para autores, constante no final de cada fascículo.}

